Science, Technology and Development 35 (1): 26-34, 2016

ISSN 0254-6418 / DOI: 10.3923/std.2016.26.34

(C) 2016 Pakistan Council for Science and Technology

\title{
Density and Taxonomic Diversity of Understory Vegetation in Relation to Site Conditions in Natural Stands of Acacia modesta in Malakand Division, Khyber Pakhtunkhwa, Pakistan
}

\author{
Zahid Muhammad, Nasrullah Khan, Shaukat Ali, Atta Ullah and Shahid Mahmood Khan \\ Laboratory of Plant Ecology, Department of Botany, University of Malakand, \\ Chakdara, Dir Lower, Pakistan
}

\begin{abstract}
Site ecological factors have great influence on the vegetation density, distribution and diversity. Its prediction is of prime importance for the forest ecosystem conservation and management. Therefore, density, taxonomic diversity and distribution of understory vegetation on varied soil and topographic conditions of 32 Acacia modesta (Wall) d ominating forests in Malakand Division between an elevation ranging from 598-1050 m above sea level, in Northern Pakistan $\left(71^{\circ} 03-72^{\circ} 04\right.$ E Longitude and $34^{\circ} 31-34^{\circ} 45$ N Latitude) were studies during 2013-14. These forests for ecological attributes were sampled by laid down 20 quadrates of $5 \times 5 \mathrm{~m}$ along a line transect of $200 \mathrm{~m}$ with 10 step intervals. Site physiographic and soil physiochemical features were also analyzed for each forest stand. A total of 3836 individuals (plants), comprising 32 species and belonging to 20 angiosperms families were recorded. The analysis of understory vegetation revealed that Asteraceae, Poaceae and Sapindaceae were the dominant families in terms of taxonomic diversity and Family Importance Value (FIV) index, respectively. The members of Chenopodiaceae and Poaceae were distributed on six different aspects. However, species richness and diversity were generally high on East and West aspects of the study area. Dodonea viscosa (L.) Jacq was the dominant shrub species in terms of density and percent cover. In addition, percent species and abundance show contrast variations with relative frequency. The site environment and species relationship show that lower basicity, high sand and water contents have a great influence on the plant species diversity and richness. The results suggested that certain physiographic and edaphic variables confined the species richness, diversity and distribution of the vegetation in the study area.
\end{abstract}

Key words: Density, diversity, environmental variables, asteraceae, Dodonea viscosa

\section{INTRODUCTION}

Forest floor play an ecological role in nutrients recycling, preserving habitats for various individuals, protection, herbaceous layer renovation and establishment of balance in communities and ecosystems (Ahmad et al., 2014). Vegetation of the forests floor with a definite structure and composition are retained by the combined interaction of long term biotic and abiotic factors on spatial and temporal scales and slight variations of which disturb the ecosystem balance. According to Bhatt and Khanal (2010), structure and composition of a forest floor is mainly influenced by certain human impacts, which make changes in other external factors of disturbances.

Composition and diversity of vegetation is reflecting by the site gradients and study of which is of a central theme in vegetation ecology (Zhuang et al., 2012). Site gradients, i.e., physiographic and edaphic, draw the sketch of species assemblage and abundance and the numerical analysis of such factors are of prime importance for the biodiversity conservations and renovation of balance ecosystems (Mataji et al., 2010). Previous studies have described that site environmental factors are relatively linked in a natural way with taxonomic diversity, density and distribution pattern of species (Kratochwil, 1999; Sarwar and Qaiser, 2012; Tian et al., 2013).

Species diversity firmed by evolutionary and ecological processing governs variations in associations of an ecosystem (Pianka, 1966; Kuusipalo, 1984) has two components, i.e., evenness and species richness (Stirling and Wilsey, 2001). Similarly, equitability, an important biodiversity index, determines the total variation in each community by sharing its own ecological functional attributes (Tilman, 2000). The regional changes in species distribution and diversity largely depends upon the covered area, association between local and native species diversity while spatial gradients like latitude, longitude, elevation, environmental factors including soil factors and productivity determine diversity pattern (Gaston, 2000). Maximum species diversity and density of an area

Corresponding Author: Zahid Muhammad, Laboratory of Plant Ecology, Department of Botany, University of Malakand, Chakdara, Dir Lower, Pakistan 
represents highly fertile soil, affecting the vegetation composition in different ways however, species diversity may be one of the adoptive feature to site conditions (Ahmad et al., 2009). Analysis of taxonomic diversity and density of plants in the natural habitat is used for measuring productivity and their adoptability to environment with ecological importance and information are extremely crucial for understanding forest dynamics (Gentry, 1990; Hartshorn, 1990; Reddy et al., 2007). Developed countries use scientific measures for the assessment of biodiversity resources, its conservation and utilization. They seek to make sure that right to use is regulated and ensure self-regulated distribution of remuneration through proper and timely transfer of technology and finance (Latif and Shinwari, 2005). In less developed countries, like Pakistan, there are many problems to biodiversity and conservation, due to which these countries cannot develop and properly utilize their forest resources in meaningful ways. Therefore, this study was conducted to determine the density, diversity and distribution of understory vegetation in Acacia modesta natural stands of Malakand division, Khyber Pakhtunkhwa, Pakistan along site gradients in order to provide baseline information for its conservation and management.

\section{MATERIALS AND METHODS}

Study site: The study was conducted during 2013-14 in thirty forest stands dominated by Acacia modesta in four districts of Malakand division (i.e., district Malakand, Dir Lower, Western lower and upper areas of Swat and Buner) at an elevation ranged from 598-1050 m above sea level. The study area is spanning between $71^{\circ} 03-72^{\circ} 04 \mathrm{E}$ Longitude and $34^{\circ} 31-34^{\circ} 45 \mathrm{~N}$ Latitude in Northern Pakistan. Physiographic features revealed an uneven distribution of mountains, foothills and plains which greatly affect the climate of the area from South to North (Shariatullah, 2013). Climatic data, taken from Karachi Metrological Department, shows a mean annual temperature of $16^{\circ} \mathrm{C}$ (lowest $5^{\circ} \mathrm{C}$ in January, highest $26^{\circ} \mathrm{C}$ in July). June and July are the hottest while December and January are the coldest months of the year. Vegetation of the study area receive water in the form of precipitation, bulk of which are coming from winter rain and snow fall $(625 \mathrm{~mm})$ during February to April and Monsoon (325 mm) during July and August (Wahab et al., 2008). Maximum rainfall was recorded during February and March (246 mm), whereas, percent relative humidity was high throughout the year. The rock ancestors are igneous and meta-sediment rocks belonging to Precambrian and lower Paleozoic era (Hussain, 2002). In the study area, Sino-Japanese elements are dominant defining high floristic diversity and ecological significance of the study area (Sher and Al-Yamini, 2011), with a number of broadleaved, deciduous and conifer forests (Bibi, 2012). Among the broadleaved and deciduous species, Olea ferruginea, Quercus baloot, Quercus incana, Monotheca buxifolia, Acacia modesta, Punica granatum were common trees whereas, Dodonea viscosa, Justiscia adhatoda, Otestigia lambita, Mallotus were the representative shrubby species of the study area (Khan et al., 2015). The deciduous forests are distributed at low elevation $(<1500 \mathrm{~m})$, while evergreen conifer forests are between 700-3000 m elevation (Khan et al., 2014).

Field methods: Thirty two sites with least disturbance history covering at least an area of 1 ha were selected for the analysis of understory vegetation density, distribution and taxonomic diversity. Before vegetation analysis, geographical characteristics were recorded for each stand (latitude and longitude) using Global Positioning System (GPS). The topographic parameters like slope exposure, aspect and elevation were recorded using clinometers, magnetic compass and altimeter respectively. Each stand was studied by 10 quadrates of $5 \times 5 \mathrm{~m}$ laid regularly on a line transect of 200 meter with an interval of 10 steps following Shaheen et al. (2011). Ecological appraisal, i.e., types of species, their density and canopy coverage was measured for each understory species in each site following standard procedure described by Ahmed and Shaukat (2012). Plant specimens were identified, using different identification manuals and flora of Pakistan (Nasir and Ali, 1972). Sample specimens were pressed and preserved on standard herbarium sheets at the laboratory of Plant Ecology, Department of Botany, University of Malakand. From each stand composite soil samples were obtained from top to $15 \mathrm{~cm}$ depth for the analysis of chemical and physical properties.

Soil analysis: For soil texture analysis (i.e., sand, silt and clay) hydrometer method of Koehler et al. (1984) was employed. Soil $\mathrm{pH}$ was determined by soil digital $\mathrm{pH}$ meter (model: HI 99121), using 1:5 soil water suspensions (Mclean, 1982). $\mathrm{CaCO}_{3}$ was analyzed by acid neutralization method of Black (1965) while soil organic matter was determined, using standardized solution of $\mathrm{FeSO}_{4}$ and $\mathrm{K}_{2} \mathrm{Cr}_{2} \mathrm{O}_{7}$ as given by Nelson and Sommer (1982). AB-DTPA or Mehlic No.3 extractible P and K was determined in samples on the basis of $\mathrm{pH}$ of soil samples. In case of low pH (below 7), Mehlic-3 extractant was used while for $\mathrm{pH}$ greater than 7 AB-DTPA extract was used respectively. Soil water properties (i.e., field capacity, wilting point, saturation, conductivity and available water) were estimated from soil texture 
composition using online hydraulic properties calculator. For accurate results five replicas were analyzed and their mean values were used in the results.

Numerical analysis: Absolute values of each stand like density/ha and cover $\left(\mathrm{m}^{2} \mathrm{ha}^{-1}\right)$ was measured for individual species in each sampling plot following Mueller-Dombois and Ellenberg (1974). Shannon and Weaver (1963) and Simpson (1949), the most popular diversity indices were used to assess stand diversity, where $p_{i}$ is the proportion of ith species in case of Shannon and Weaver (1963) diversity as in Eq. 1, while $\mathrm{N}$ is the observation of the respective species in the formula given by Simpson (1949) as in Eq. 2. These diversity indices have great accuracy for biodiversity sampling and are used throughout the world:

$$
\begin{gathered}
\mathrm{H}^{\prime}=-\sum_{\mathrm{i}=1}^{\mathrm{s}} \mathrm{pi} \ln (\mathrm{pi}) \\
\mathrm{D}=\frac{\mathrm{N}(\mathrm{N}-1)}{\sum \mathrm{n}(\mathrm{n}-1)}
\end{gathered}
$$

Stands equitability or evenness (J) (Pielou, 1977) as in Eq. 3 and species richness (d) (Menhinick, 1964) as in Eq. 4 were calculated using the following equation:

$$
\begin{aligned}
& J=\frac{\mathrm{H}^{\prime}}{\operatorname{lnS}} \\
& \mathrm{d}=\frac{\mathrm{n}}{\sqrt{\mathrm{N}}}
\end{aligned}
$$

where, $\ln S$ is the natural log of number of species $n$ (number of species) and $\mathrm{N}$ total density of all the species. Maturity Index (M.I) of the communities were determined by the method described by Pichi-Sermolli (1948), using Eq. 5.

$$
\text { M.I }=\frac{F}{n}
$$

In addition, Relative Frequency (RF) and density/ha were calculated for each species in all the sampled stands. Relative frequency classes were prepared on intervals of 10 and species (\%) and their abundance (\%) were presented in the form of bar graph (Fig. 1). Family Importance Value (FIV) was also calculated for each family as total species of a family/total species of all families $\times 100+$ family relative density following Mori et al. (1983). For the comprehensive study of ecological diversity in the research area the plots were grouped into 7 major communities on the basis of aspect, i.e., N, E, W, S, NE, NW and SW, facing slopes.

\section{RESULTS AND DISCUSSION}

Environmental variables: The details of site environmental parameters (i.e., topographic, edaphic and soil) are shown in Table 1. North facing slopes have slightly basic $\mathrm{pH}$ values, rich in organic matter and Nitrogen content while wilting point is extremely high due to steep slopes. East facing slopes is characterized by high sand content and conductivity value with high basic $\mathrm{pH}$. West facing slopes are less fertility while slightly basic in nature. Vegetation of South facing slopes occurs on extremely high altitude and generally rich in Phosphorus and potassium contents. North-east slopes are rich in potassium and $\mathrm{CaCO}_{3}$ contents while soil available water, conductivity and saturation is high as compared to other stands. North-West slopes are rich in organic matter, Nitrogen (\%) and lime contents with high soil water availability, conductivity, field capacity and wilting point. The soils on north-west exposures are generally basic in nature in the study area (Table 1). However, it was observed that south-west slopes are sandy and highly basic in nature with comparatively moderate contents of potassium and phosphorus. However, lime (\%) contents and conductivity was high on these exposures.

Taxonomic diversity: The forests understory species of herbs and shrubs in Acacia modesta forests were constituted of 20 families and 32 herbs and shrubs species. Of these families $95 \%$ were dicotyledonous with 91\% species. Individual aspects show great variations in species richness, of which 10 species occurred on North, 25 on East, 23 West, 14 South, 6 on North-East and North-West each and 8 on South-West facing aspects, respectively (Table 2). Highest species richness were observed for family Asteraceae (6 species) and Poaceae (3 species). Three families were characterized by 2 species each, while the remaining 15 families comprised 1 species each. Chenopodiaceae and Poaceae were distributed on 6 aspects, while families such as Apocynaceae, Verbinaceae and Rhamnaceae were limited to single aspect. On North facing slopes the dominant family was Poaceae with 3 species followed by Amaranthaceae, Euphorbiaceae, Celastraceae, Lamiaceae, Sapindaceae, Thymeliaceae and Tiliaceae with 1 species each. Slopes with East and West facing exposure were dominated by Asteraceae (5 species) followed by Poaceae (3 species), Euphorbiaceae and Solanaceae with 2 species each. South facing slopes were dominated by Poaceae ( 3 species), while the remaining families, 
Sci. Technol. Dev., 35 (1): 26-34, 2016

Table 1: Mean values of soil features of the study sites along aspect

\begin{tabular}{|c|c|c|c|c|c|c|c|}
\hline Site parameters & North & East & West & South & North-East & North-West & South-West \\
\hline$\overline{\text { Elevation (m) }}$ & $816 \pm 23$ & $826 \pm 61$ & $830.57 \pm 64.16$ & $861 \pm 36$ & $689 \pm 30$ & $638 \pm 41$ & $715 \pm 117$ \\
\hline Slope $\left(^{\circ}\right)$ & $53 \pm 1.15$ & $42.62 \pm 7.45$ & $36.57 \pm 8.10$ & $51.4 \pm 2.90$ & $5 \pm 1$ & $6.66 \pm 0.88$ & $19.5 \pm 14.5$ \\
\hline Clay (\%) & $17.46 \pm 66$ & $17 \pm 0.6$ & $19.2 \pm 1.42$ & $18 \pm 1.01$ & $21.8 \pm 1$ & $22.13 \pm 1.76$ & $14.8 \pm 00$ \\
\hline Silt (\%) & $26.66 \pm 6.76$ & $19.5 \pm 0.5$ & $24.57 \pm 6.51$ & $26.4 \pm 6.11$ & $39 \pm 5$ & $36.66 \pm 6.76$ & $22 \pm 00$ \\
\hline Sand (\%) & $55.86 \pm 6.56$ & $63.45 \pm 4.84$ & $57.37 \pm 6.94$ & $55.6 \pm 6.93$ & $39.2 \pm 4$ & $41.2 \pm 5.29$ & $63.2 \pm 00$ \\
\hline $\mathrm{pH}$ & $7.33 \pm 0.17$ & $7.46 \pm 0.14$ & $7.35 \pm 0.14$ & $7.36 \pm 0.13$ & $7.75 \pm 0.25$ & $7.8 \pm 00$ & $7.9 \pm 0.1$ \\
\hline $\operatorname{ter}(\%)$ & $2.57 \pm 0.44$ & $1.81 \pm$ & $1.72 \pm$ & $1.79 \pm 0.25$ & $2.24 \pm 0.17$ & $2.76 \pm 0.79$ & $1.41 \pm 0.37$ \\
\hline Lime (\%) & $5 \pm 0$ & $5.93 \pm 0.29$ & $7.5 \pm 1.96$ & $6.9 \pm 1.93$ & $10 \pm 5$ & $13.33 \pm 3$ & $8.5 \pm 1.5$ \\
\hline $\mathrm{N}(\%)$ & $0.12 \pm 0.02$ & $0.09 \pm 0.03$ & $0.08 \pm 0.02$ & $0.08 \pm 0.01$ & $0.11 \pm 0.08$ & $0.13 \pm 0.03$ & $0.07 \pm 0.01$ \\
\hline $\mathrm{P}\left(\mathrm{mg} \mathrm{kg}^{-1}\right)$ & $4.56 \pm 0.82$ & $5.22 \pm 0.22$ & $4.34 \pm 0.48$ & $7.71 \pm 2.56$ & $4.10 \pm 1.97$ & $4.36 \pm 0.36$ & $5.98 \pm 0.09$ \\
\hline $\mathrm{K}\left(\mathrm{mg} \mathrm{kg}^{-1}\right)$ & $149.33 \pm 26.69$ & $121.5 \pm 15.9$ & $138 \pm 12.69$ & $187.6 \pm 57.33$ & $285 \pm 45$ & $116.66 \pm 14.43$ & $156 \pm 74$ \\
\hline Wilting point $\left(\mathrm{cm}^{3}\right.$ water $\mathrm{cm}^{-3}$ soil $)$ & $0.13 \pm 0.01$ & $0.11 \pm 0.02$ & $0.12 \pm 0.05$ & $0.11 \pm 0.03$ & $0.13 \pm 0.05$ & $0.13 \pm 0.08$ & $0.10 \pm 00$ \\
\hline Field capacity $\left(\mathrm{cm}^{3}\right.$ water $\mathrm{cm}^{-3}$ soil $)$ & $0.24 \pm 0.01$ & $0.21 \pm 0.01$ & $0.23 \pm 0.01$ & $0.23 \pm 0.01$ & $0.26 \pm 0.03$ & $0.26 \pm 0.026$ & $0.21 \pm 00$ \\
\hline Saturation $\left(\mathrm{cm}^{3}\right.$ soil $\mathrm{cm}^{-3}$ soil $)$ & $0.45 \pm 0.01$ & $0.44 \pm 0.03$ & $0.45 \pm 0.08$ & $0.45 \pm 0.07$ & $0.47 \pm 00$ & $0.42 \pm 00$ & $0.43 \pm 00$ \\
\hline Conductivity $\left(\mathrm{cm} \mathrm{h}^{-1}\right)$ & $0.77 \pm 0.18$ & $1.06 \pm 0.09$ & $0.91 \pm 0.12$ & $1 \pm 0.09$ & $0.73 \pm 0.11$ & $0.73 \pm 0.18$ & $1.37 \pm 00$ \\
\hline Available water $\left(\mathrm{cm}^{3}\right.$ soil $\mathrm{cm}^{-3}$ soil $)$ & $0.10 \pm 00$ & $0.10 \pm 00$ & $0.10 \pm 0.01$ & $0.11 \pm 0.01$ & $0.13 \pm 00$ & $0.13 \pm 0.01$ & $0.10 \pm 00$ \\
\hline
\end{tabular}

Table 2: Taxonomic diversity of angiosperm understory of study sites along aspect

\begin{tabular}{|c|c|c|c|c|c|c|c|c|c|c|}
\hline Family & North & East & West & South & North-East & North-West & South-West & Species & Density & FIV \\
\hline Asteraceae & 0 & 5 & 5 & 0 & 2 & 1 & 1 & 6 & 728.00 & 38 \\
\hline Asclapidaceae & 0 & 1 & 0 & 1 & 0 & 0 & 0 & 1 & 33.00 & 4 \\
\hline Amaranthaceae & 1 & 0 & 2 & 1 & 0 & 1 & 0 & 2 & 88.00 & 9 \\
\hline Acanthaceae & 0 & 1 & 1 & 1 & 0 & 0 & 1 & 1 & 278.00 & 10 \\
\hline Apocynaceae & 0 & 0 & 1 & 0 & 0 & 0 & 0 & 1 & 1.25 & 3 \\
\hline Cannabaceae & 0 & 1 & 0 & 0 & 0 & 1 & 0 & 1 & 173.00 & 8 \\
\hline Chenopodiaceae & 0 & 1 & 1 & 1 & 1 & 1 & 1 & 1 & 321.00 & 11 \\
\hline Cactaceae & 0 & 1 & 0 & 1 & 0 & 0 & 0 & 1 & 9.00 & 3 \\
\hline Celastraceae & 1 & 1 & 1 & 1 & 0 & 0 & 1 & 1 & 42.00 & 4 \\
\hline Euphorbiaceae & 1 & 2 & 1 & 1 & 0 & 0 & 0 & 2 & 33.50 & 7 \\
\hline Lamiaceae & 1 & 1 & 2 & 1 & 0 & 0 & 2 & 2 & 178.00 & 11 \\
\hline Malvaceae & 0 & 0 & 1 & 0 & 1 & 0 & 0 & 1 & 19.00 & 4 \\
\hline Poaceae & 3 & 3 & 3 & 3 & 1 & 0 & 1 & 3 & 910.00 & 33 \\
\hline Rhamnaceae & 0 & 1 & 0 & 0 & 0 & 0 & 0 & 1 & 1.25 & 3 \\
\hline Solanaceae & 0 & 2 & 1 & 1 & 0 & 1 & 0 & 3 & 183.25 & 14 \\
\hline Scrophulariaceae & 0 & 1 & 1 & 0 & 1 & 1 & 0 & 1 & 85.00 & 5 \\
\hline Sapindaceae & 1 & 1 & 1 & 1 & 0 & 0 & 1 & 1 & 715.00 & 22 \\
\hline Thymeliaceae & 1 & 1 & 1 & 0 & 0 & 0 & 0 & 1 & 25.00 & 4 \\
\hline Tiliaceae & 1 & 1 & 1 & 1 & 0 & 0 & 0 & 1 & 5.00 & 3 \\
\hline Verbinaceae & 0 & 1 & 0 & 0 & 0 & 0 & 0 & 1 & 7.50 & 3 \\
\hline Total & 10 & 25 & 23 & 14 & 6 & 6 & 8 & 32 & 3835.75 & 199 \\
\hline
\end{tabular}

FIV: Family importance value

like, Asclapidaceae, Amaranthaceae, Acanthaceae, Chenopodiaceae, Cactaceae, Sapindaceae, Euphorbiaceae, Solanaceae, Celastraceae, have one specie each. North-east slopes have Asteraceae as the dominant family (2 species) while Malvaceae, Poaceae and Chenopodiaceae contributed a single species in the floristic diversity. On North-West slopes the Asteraceae, Amaranthaceae, Chenopodiaceae and Solanaceae were equally distributed in terms of species number. South-west slopes were characterized by Lamiaceae (2 species), Asteraceae, Chenopodiaceae, Poaceae and Celastraceae (1 species each). The results show that Maximum Family importance value (FIV) index was represented by Asteraceae (38) and Poaceae (33), followed by Sapindaceae (22), respectively (Table 2).

Species richness and diversity: Average number of species varied spatially on each aspect exposure and ranged from 6-25 individuals. East and West slopes were the dominant aspects in terms of species richness (25 and 23), of which South and South-West had 8 and North-East and North West had 6 species each. Mean specie richness was the highest for East (0.73) and West (0.62) and the lowest on North-East (0.25) followed by North-West (0.30) aspects, respectively (Table 3). Mean values of Shannon-Weaver diversity and evenness was lowest on North-East facing slopes representing disturbed communities due to high demand of some plants for domestic uses and other anthropogenic interventions of the local inhabitants. Similarly, these values were highest for East facing slopes with sandy and acidic soils. These results are also verified by Simpson dominance values, i.e., lower values of Simpson dominance, indicated high diversity status sharing by many plant species as indicted from East aspect. North, West and South aspect showed intermediate characteristics of diversity and equitability. 
Sci. Technol. Dev., 35 (1): 26-34, 2016

Table 3: Average diversity indices of 7 major Aspect positions of understory vegetation

\begin{tabular}{lrrrrrrr}
\hline Diversity indices & North & East & West & South & North-East & North-West & South-West \\
\hline Richness (d) & 0.56 & 0.73 & 0.62 & 0.46 & 0.25 & 0.30 & 0.45 \\
Simpson (D) & 0.42 & 0.27 & 0.32 & 0.41 & 0.66 & 0.45 & 0.53 \\
Shanon-Weiner (H') & 1.08 & 1.52 & 1.27 & 1.04 & 0.68 & 0.87 & 0.95 \\
Evenness (J) & 0.74 & 0.77 & 0.72 & 0.70 & 0.67 & 0.87 & 0.59 \\
Maturity index (M.I) & 25.60 & 15.00 & 18.25 & 23.33 & 41.66 & 25.12 & 25.00 \\
\hline
\end{tabular}

Table 4: Mean density/ha and cover $\mathrm{m}^{2} \mathrm{ha}^{-1}$ of understory vegetation with standard error

\begin{tabular}{|c|c|c|}
\hline Species & $\begin{array}{l}\text { Density } \\
\left(\mathrm{ha}^{-1}\right)\end{array}$ & $\begin{array}{l}\text { Cover } \\
\left(\mathrm{m}^{2} \mathrm{ha}^{-1}\right)\end{array}$ \\
\hline Dodonea viscosa (L.) Jacq & $715 \pm 157$ & $304 \pm 73$ \\
\hline Daphne oleoides Schreb & $25 \pm 17$ & $7 \pm 6$ \\
\hline Calotropis procera (Ait) R. $\mathrm{Br}$ & $33 \pm 24$ & $34 \pm 28$ \\
\hline Gymnosporia royleana Wall. ex Lawson & $42 \pm 12$ & $4 \pm 2$ \\
\hline Otostegia limbata (BTH.) BOISS & $108 \pm 39$ & $15 \pm 9$ \\
\hline Vitex negundo L. & $7.5 \pm 7.5$ & $2.25 \pm 2.25$ \\
\hline Justicia adhatoda Linn. & $278 \pm 95$ & $125 \pm 44$ \\
\hline $\begin{array}{l}\text { Zizyphus nummularia (Burm. f.) } \\
\text { Wight and Arn. }\end{array}$ & $1.25 \pm 1.25$ & $0.4 \pm 0.4$ \\
\hline $\begin{array}{l}\text { Mallotus philippensis (Lam.) } \\
\text { Möll. Arg. }\end{array}$ & $31 \pm 15$ & $14 \pm 8$ \\
\hline Nerium indicum -Mill. & $1.25 \pm 1.25$ & $0.18 \pm 0.18$ \\
\hline Grewia optiva J.R. Drumm. ex Burret & $5 \pm 2$ & $0.62 \pm 0.62$ \\
\hline Opentia dilleni Haw & $9 \pm 6$ & $0.12 \pm 0.12$ \\
\hline Datura innoxia Miller & $1.25 \pm 1.25$ & $0.003 \pm 0.003$ \\
\hline Amaranthus viridis $\mathrm{L}$. & $75 \pm 40$ & $8 \pm 5$ \\
\hline Achyranthes aspera L. & $13 \pm 9$ & $0.005 \pm 0.003$ \\
\hline Ajuga bracteosa Wall ex. Benth & $70 \pm 39$ & $5 \pm 4$ \\
\hline Carthamus oxycantha Bieb & $140 \pm 64$ & $16 \pm 10$ \\
\hline Chenopodium album L. & $321 \pm 116$ & $64 \pm 27$ \\
\hline Cannabis sativa $\mathrm{L}$. & $173 \pm 92$ & $22 \pm 16$ \\
\hline Cymbopogon distans Nees ex Steud & $459 \pm 134$ & $18 \pm 10$ \\
\hline Conyza canadensis (L.) Cronquist & $230 \pm 138$ & $64 \pm 50$ \\
\hline Cenchrus ciliaris L. & $250 \pm 85$ & $6 \pm 3$ \\
\hline Euphorbia hirta Linn & $2.5 \pm 2.5$ & $0.001 \pm 0.001$ \\
\hline Malvastrum tricuspidatum L. & $19 \pm 18$ & $1.85 \pm 1.80$ \\
\hline Parthenium hysterophorus L. & $183 \pm 105$ & $6 \pm 5$ \\
\hline Sonchus asper L. & $61 \pm 44$ & $7 \pm 5$ \\
\hline Solanum nigrum L. & $174 \pm 107$ & $34 \pm 22$ \\
\hline Solanum surattense Burm.f. & $8 \pm 6$ & $3 \pm 3$ \\
\hline Saccharum griffthii Munro. Ex Boiss. & $201 \pm 81$ & $15 \pm 13$ \\
\hline Tagetes minuta L. & $101 \pm 71$ & $0.65 \pm 0.46$ \\
\hline Verbascum thapsus L. & $85 \pm 36$ & $8 \pm 5$ \\
\hline Xanthium strumarium $L$. & $13 \pm 10$ & $0.31 \pm 0.32$ \\
\hline
\end{tabular}

These communities were located on rich soils and high altitudes. Shannon-Weaver and Simpson diversity indices were found conflicting and one increase caused decrease in other value. Communities facing North-East, North-West, North and South-West aspects were highly mature, while East and West facing slopes were poorly developed. Overall relative frequency distributions of the species (\%) along with their abundance (\%) are shown side by side (Fig. 1). About $43 \%$ of species with $7 \%$ of total abundance were found within narrow relative frequency range, while 13\% species (with 36\% abundance) were found with high relative frequency ranges.

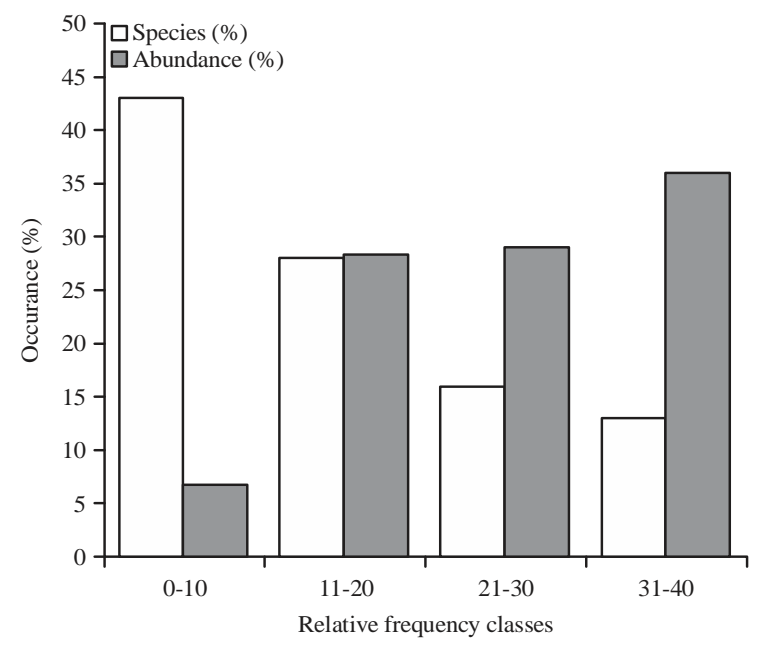

Fig. 1: Percent distribution of species and their abundance in a variety of relative frequency classes

Density ha ${ }^{-1}$ and cover $\left(\mathbf{m}^{2} \mathbf{h a}^{-1}\right)$ : The average density/ha and cover $\left(\mathrm{m}^{2} \mathrm{ha}^{-1}\right)$ were recorded for 32 understory species and they belonged to 20 families in 30 stands and they were grouped in 7 major plots based on their exposure (Table 4). From the results it is clear that each species has its own structural and ecological status in terms of density ha ${ }^{-1}$ and cover $\left(\mathrm{m}^{2} \mathrm{ha}^{-1}\right)$. The maximum average number of individual's ha ${ }^{-1}(715 \pm 157)$ was recorded for Dodonea viscosa (L.) with a mean cover of $304 \pm 73 \mathrm{~m}^{2} \mathrm{ha}^{-1}$ as a leading species. Among other twelve species, Otostegia limbata, Justicia adhatoda, Carthamus oxycantha, Chenopodium album, Cannabis sativa, Cymbopogon distans, Conyza Canadensis, Cenchrus ciliaris, Parthenium hysterophorus, Solanum nigrum, Saccharum griffthii and Tagetes minuta occurred with a mean density ranging from 100-460 individuals $\mathrm{ha}^{-1}$, while the cover ranged from $0.65-1.25\left(\mathrm{~m}^{2} \mathrm{ha}^{-1}\right)$ as co-dominants species. These co-dominants species were found to be distributed excessively in majority of the stands. Such co-dominants can be recruited as community dominant species in future. From the results given in Table 4, it is also evident that Zizyphus nummularia, Nerium indicum, Datura innoxia, Calotropis procera, Daphne oleoides, Vitex negundo, Grewia optiva, Verbascum thapsus, Amaranthus viridis, Ajuga bracteosa shared a mean 
density of $1.25-85$ individuals ha ${ }^{-1}$ with an average cover ranging from $0.003-34 \mathrm{~m}^{2} \mathrm{ha}^{-1}$. These species have very low share and can be diminishing in future under the prevailing conditions. Based on family density, Poaceae 910 (24\%), Asteraceae 728 (19\%) and Sapindaceae 715 (18\%) were the dominant families in the study area.

A total of 32 understory species including herbs and shrubs were recorded in Acacia modesta dominated forests from the study area. The vegetation analysis showed that the dominant species in terms of density were Dodonea viscosa, Cymbopogon distans, Chenopodium album, Justicia adhatoda, Cenchrus ciliaris and Conyza canadensis. On the other hand, Dodonea viscosa, Justicia adhatoda, Chenopodium album and Conyza Canadensis were the dominant individuals in terms of canopy cover. The dominant families were Poaceae and Asteraceae that shared 3-5 species and had been reported by Shah and Rozina (2013) from the nearby district with the same proportion.

Chenopodiaceae and Poaceae were distributed on 6 different aspects while Asteraceae, Celasteraceae and Sapindaceae on 5 aspects each. These results indicated that members of these families are growing well on all aspects. However, the species of other families were restricted to particular aspects which suggest that the specific physiographic conditions support different species. Several workers have emphasized the role of aspects on the specific vegetation distribution in different areas of Pakistan and even in the world. Khan et al. (2011) reported that Monotheca buxifolia grow well on eastern aspects, Quercus baloot on the South-East (Khan, 2012) and Pinus roxburghii on Northern aspects (Siddiqui et al., 2009; Khan et al., 2014) with specific understory species in northern Pakistan. Somewhat similar findings were also reported by Shariatullah (2013) in Justicia shrub-land and most recently by Ali (2016) in Olea ferruginea dominated forests from Malakand division.

The present analysis of understory vegetation also suggested that overall, Acacia modesta forests were poorly developed in terms of species richness and taxonomic diversity. These poorly developed communities of understory species in the study area indicate improper management and lack of conservation practices. This causes disproportional development of an ecosystem, unhealthy ecological characteristics to provide habitats, palatable and consumable herbs, shrubs and wood species for domestic and wild animals (Arshad et al., 2013). De Bello et al. (2013) and Zuo et al.
(2012) stated that, variations in species diversity, density and distribution of different communities were characterized by site ecological amplitude. Determination of ecological amplitude of a an area is determined by the altitudinal gradients effecting climatic conditions, which then cause variations in vegetation distribution (Wolf, 1994; Lieberman et al., 1996). Geographical distribution, soil physiochemical features, precipitation, succession stages and conservation status also influence species richness, abundance and diversity (Plumptre, 1996).

In the present study, moderate elevation, slope degree, high sand contents and conductivity are found to have a major role in species distribution in terms of diversity and richness. Such variation in the physiographic and soil factors are modifying light, temperature and water contents and also affect the bioclimatic condition of the particular sites constituting diverse vegetation zones at various spatial and organizational levels. Some of the diverse vegetation represented different types of species, with their relative dominance level, composition, inter-specific competitions and associations, temporal and spatial changes with their ecological properties and role. Climax zonation of overlapped species richness and evenness are formed after long term stable environmental conditions (Kharkwal et al., 2010).

In this study, annual species were more than perennials due to the adaptability to varied site conditions as reported by Poorter (1999). From the results, it is evident that East facing slopes were more diverse as compared to others. This study also revealed the importance of the topographic and soil physiochemical properties in determining species richness and abundance. There were differences in diversity, composition and structures from East to North-East and North-West exposure with species tolerant from slightly basic to more basic and loamy to sandy soils. This study not only suggested the role of geographical positions but also the importance of soil basicity, physical characteristic and nutrients status that were appeared to be the vegetation effectors on different topographic situations.

The results exposed that lower basicity, high sand and water contents had the greatest influence on plant species diversity and richness. Taxonomic diversity and vegetation distribution of the study area indicate vast variety of microclimate in the area. These variations in species diversity and density are due to anthropogenic activities and site ecological characteristics. Cosmopolitan nature of family Chenopodiaceae and Poaceae on almost all aspects revealed their adaptation to a variety of 
topographic constrain, while high FIV value and the density of Asteraceae, Poaceae and Sapindaceae may be possibly, due to their high dispersion mechanism or nature (Chittibabu and Parthasarathy, 2000).

\section{CONCLUSIONS}

We assessed the density and taxonomic diversity of understory vegetation in Acacia modesta dominated forests in Malakand Division and concluded that the study sites were generally poor in species richness and were dominated by individuals of family Asteraceae and Poaceae. The results also suggested that species' diversity was higher on east facing slopes with sandy soils and high conductivity values. Dodonea viscosa appeared to be the dominant shrub throughout the study sites with the highest density/ha and cover $\left(\mathrm{m}^{2} \mathrm{ha}^{-1}\right)$, which may be due to its high ecological amplitude. From the results, we also concluded that decrease in species richness was somehow linked with decreasing elevation, which may be due to the excessive exposure of vegetation to a number of anthropogenic activities in the study area. It is suggested that these threatened understory vegetation need special attention of the biologists, foresters and conservationists for sound conservation on scientific basis.

The authors are extremely thankful to Dr. Kishwar Ali, Department of Biological Sciences, University of Reading, UK, for his valuable comments on the early draft of this manuscript. Authors are also indebted to unknown reviewers whom critical review significantly improved the quality of the manuscript.

\section{REFERENCES}

Ahmad, S.S., S. Erum, S.M. Khan and M. Nawaz, 2014. An appraisal of ecological distribution of herbaceous flora at Changa Manga park Lahore, Pakistan. Pak. J. Bot., 46: 19-25.

Ahmad, S.S., S. Fazal, E.E. Valeem, Z.I. Khan, G. Sarwar and Z. Iqbal, 2009. Evaluation of ecological aspects of roadside vegetation around Havalian city using multivariate techniques. Pak. J. Bot., 41: 53-60.

Ahmed, M. and S.S. Shaukat, 2012. A Text Book of Vegetation Ecology. Abrar Sons, Karachi, Pakistan, Pages: 396.

Ali, F., 2016. Structural dynamics and dendero-ecology of Olea ferruginea forests in Hindukush ranges of Malakand division, Pakistan. M. Phil. Thesis, University of Malakand, Chakdara, Dir, Khyber Pakhtunkhwa, Pakistan.
Arshad, M., R.N. Malik and Z. Saqib, 2013. Assessing potential habitats of Kashmir Markhor in Chitral Gol National Park, Khyber Pakhtunkhwa, Pakistan. Pak. J. Bot., 45: 561-570.

Bhatt, R.P. and S.N. Khanal, 2010. Vegetation analysis and differences in local environment variables in Indrawati hydropower project areas in Nepal. Int. Res. J. Plant Sci., 1: 83-94.

Bibi, S., 2012. Phyto-ecological and Ethnobotanical study of inter cropping weeds in wheat of Adenzi Valley, District Dir Lower, Pakistan. M. Phil. Thesis, University of Malakand, Chakdara, Pakistan.

Black, C.A., 1965. Methods of Soil Analysis-Part II. America Society of Agronomy, Madison, WI., USA., Pages: 1572.

Chittibabu, C.V. and N. Parthasarathy, 2000. Understory plant diversity in a tropical evergreen forest in the Kolli hills, Eastern Ghats, India. Ecotopica, 6: 129-140.

De Bello, F., S. Lavorel, S. Lavergne, C.H. Albert, I. Boulangeat, F. Mazel and W. Thuiller, 2013. Hierarchical effects of environmental filters on the functional structure of plant communities: A case study in the French Alps. Ecography, 36: 393-402.

Gaston, K.J., 2000. Global patterns in biodiversity. Nature, 405: 220-227.

Gentry, A.H., 1990. Floristic Similarities and Differences between Southern Central America and Upper and Central Amazonia. In: Four Neotropical Rainforests, Gentry, A.H. (Ed.). Yale University Press, New Haven, CT., USA., pp: 141-157.

Hartshorn, G.S., 1990. An Overview of Neotropical Forest Dynamics. In: Four Neotropical Rainforests, Gentry, A.H. (Ed.). Yale University Press, New Haven, CT., USA., pp: 585-599.

Hussain, M., 2002. The impacts of eucalyptus plantations on the environment under the social forestry project Malakand Dir. Environmental Audit Report, Environment and Governance Series, Pakistan.

Khan, N., 2012. A community analysis of Quercus baloot Griff, forest. District Dir, Upper Pakistan. Afr. J. Plant Sci., 6: 21-31.

Khan, N., F. Ali, K. Ali and S. Shaukat, 2015. Composition, structure and regeneration dynamics of Olea ferruginea Royle forests from Hindukush range of Pakistan. J. Mountain Sci., 12: 647-658.

Khan, N., K. Ali and S. Shaukat, 2014. Phytosociology, structure and dynamics of Pinus roxburghii associations from Northern Pakistan. J. For. Res., 25: 511-521.

Khan, N., M. Ahmed, S.S. Shaukat, M. Wahab and M.F. Siddiqui, 2011. Structure, diversity and regeneration potential of Monotheca buxifolia (Falc.) A. DC. dominated forests of Lower Dir District, Pakistan. Front. Agric. China, 5: 106-121. 
Kharkwal, G., P. Mehrotra and Y.S. Rawat, 2010. Taxonomic diversity of understorey vegetation in Kumaun Himalayan forests. Life Sci. J., 7: 8-12.

Koehler, F.E., C.D. Moudie and B.L. McNeal, 1984. Laboratory Manual for Soil Fertility. Washington State University, USA.

Kratochwil, A., 1999. Biodiversity in Ecosystems: Some Principles. In: Biodiversity in Ecosystems: Principles and Case Studies of Different Complexity Levels, Kratochwil, A. (Ed.). Chapter 1, Kluwer Academic Publishers, Dordrecht, Netherlands, ISBN: 978-1-4020-0280-9, pp: 5-38.

Kuusipalo, J., 1984. Diversity pattern of the forest understorey vegetation in relation to some site characteristics. Silva Fennica, 18: 121-131.

Latif, A. and Z.K. Shinwari, 2005. Global forest resources assessment 2005: Country report-Pakistan. Forestry Department, Food and Agriculture Organization of the United Nations, Rome, Italy.

Lieberman, D., M. Lieberman, R. Peralta and G.S. Hartshorn, 1996. Tropical forest structure and composition on a large-scale altitudinal gradient in Costa Rica. J. Ecol., 84: 137-152.

Mataji, A., P. Moarefvand, S.B. Kafaki and M.M. Kermanshahi, 2010. Understory vegetation as environmental factors indicator in forest ecosystems. Int. J. Environ. Sci. Technol., 7: 629-638.

Mclean, E.D., 1982. Soil pH and Lime Requirements. In: Methods of Soil Analysis, Part 2: Chemical and Microbiological Properties, Page, A.L., R.H. Miller and D.R. Keeney (Eds.). 2nd Edn., American Society of Agronomy, Kentucky, USA., ISBN-13: 9780891180722, pp: 199-234.

Menhinick, E.F., 1964. A comparison of some species-individuals diversity indices applied to samples of field insects. Ecology, 45: 859-861.

Mori, S.A., B.M. Boom, A.M. de Carvalho and T.S. dos Santos, 1983. Southern Bahian moist forests. Bot. Rev., 49: 155-232.

Mueller-Dombois, D. and H. Ellenberg, 1974. Aims and Methods of Vegetation Ecology. 1st Edn., John Wiley and Sons, New York, USA., ISBN-13: 978-0471622901, Pages: 570.

Nasir, E. and S.I. Ali, 1972. Flora of West Pakistan. Published under P.L. 480, Research Project of USAD, with Coordination of ARC, Pakistan, pp: $1-1028$.

Nelson, D.W. and L.E. Sommers, 1982. Total Carbon, Organic Carbon and Organic Matter. In: Methods of Soil Analysis, Part 2: Chemical and Microbiological Properties, Page, A.L., R.H. Miller and D.R. Keeney (Eds.). 2nd Edn., ASA and SSSA, Madison, WI., USA., pp: 539-579.
Pianka, E.R., 1966. Latitudinal gradients in species diversity: A review of concepts. Am. Naturalist, 100: 33-46.

Pichi-Sermolli, R.E., 1948. An index for establishing the degree of maturity in plant communities. J. Ecol., 36: 85-90.

Pielou, E.C., 1977. Mathematical Ecology. 2nd Edn., Wiley-Interscience, New York, USA., ISBN: 9780471019930 Pages: 385.

Plumptre, A.J., 1996. Changes following 60 years of selective timber harvesting in the Budongo Forest Reserve, Uganda. For. Ecol. Manag., 89: 101-113.

Poorter, L., 1999. Growth responses of 15 rain-forest tree species to a light gradient: The relative importance of morphological and physiological traits. Funct. Ecol., 13: 396-410.

Reddy, C.S., C. Pattanaik, A. Mohapatra and A.K. Biswal, 2007. Phytosociological observations on tree diversity of tropical forest of Similipal biosphere reserve, Orissa, India. Taiwania, 52: 352-359.

Sarwar, G.R. and M. Qaiser, 2012. Distribution pattern, ecology and endemism of family Crassulaceae in Pakistan and Kashmir. Pak. J. Bot., 44: 2055-2061.

Shah, M. and Rozina, 2013. Phytosociological attributes and phytodiversity of Dheri baba hill and Peer Taab Graveyard, District Swabi, Khyber Pakhtunkhwa. Pakhtunkhwa J. Life Sci., 1: 1-16.

Shaheen, H., R.A. Qureshi and Z.K. Shinwari, 2011. Structural diversity, vegetation dynamics and anthropogenic impact on lesser Himalayan subtropical forests of Bagh district, Kashmir. Pak. J. Bot., 43: 1861-1866.

Shannon, C.E. and W. Weaver, 1963. The Mathematical Theory of Communication. University of Illinois Press, Urbana, Pages: 117.

Shariatullah, 2013. The status and ecology of Justicia adhatoda in Malakand division, Khyber Pakhtunkhwa, Pakistan. M.Phil. Thesis, University of Malakand, Chakdara, Dir, Lower Khyber Pukhtunkhwa, Pakistan.

Sher, H. and M. Al-Yemeni, 2011. Economically and ecologically important plant communities in high altitude coniferous forest of Malam Jabba, Swat, Pakistan. Saudi J. Biol. Sci., 18: 53-61.

Siddiqui, M.F., M. Ahmed, M. Wahab and N. Khan, 2009. Phytosociology of Pinus roxburghii Sargent (Chir Pine) in lesser Himalayan and Hindu Kush range of Pakistan. Pak. J. Bot., 41: 2357-2369.

Simpson, E.H., 1949. Measurement of diversity. Nature, 163: 688-688.

Stirling, G. and B. Wilsey, 2001. Empirical relationships between species richness, evenness and proportional diversity. Am. Nat., 158: 286-299. 
Tian, Z., P.L. Zhuang, S. Lu, W. Li, Z. Wang and Y. Liu, 2013. Characterisits of vegetation and the vertical distribution patterns on the Northern slope of the Usun Mountains, Xinjiang. Pak. J. Bot., 45: 1123-1134.

Tilman, D., 2000. Causes, consequences and ethics of biodiversity. Nature, 405: 208-211.

Wahab, M., M. Ahmed and N. Khan, 2008. Phytosociology and dynamics of some pine forests of Afghanistan. Pak. J. Bot., 40: 1071-1079.

Wolf, J.H.D., 1994. Factors controlling the distribution of vascular and non-vascular epiphytes in the Northern Andes. Vegetatio, 112: 15-28.
Zhuang, L., Z. Tian, Y. Chen, W. Li, J. Li and S. Lu, 2012. Community characteristics of wild fruit forests along elevation gradients and the relationships between the wild fruit forests and environments in the Keguqin Mountain region of Iii. J. Mountain Sci., 9: 115-126.

Zuo, X.A., J.M.H. Knops, X.Y. Zhao, H.L. Zhao, T.H. Zhang, Y.Q. Li and Y.R. Guo, 2012. Indirect drivers of plant diversity-productivity relationship in semiarid sandy grasslands. Biogeosciences, 9: 1277-1289. 